\title{
中耳結核を伴ら上咽頭結核例
}

\author{
牧石 千晶・八田 千広・深澤啓二郎
}

里見 文男・阪上 雅史

\section{Epipharyngeal Tuberculosis Accompanied by Middle Ear Tuberculosis}

\author{
Chiaki Makiishi, Chihiro Hatta, Keijirou Fukazawa, \\ Fumio Satomi and Masafumi Sakagami \\ (Hyogo College of Medicine)
}

\begin{abstract}
A case of epipharyngeal tuberculosis with middle ear tuberculosis is reported. A 41year-old female complained of left otorrhea and left facial nerve palsy. Examination of the epipharynx revealed a granular mass. A biopsy from the epipharynx showed only inflammatory changes. A smear of ear discharge and post nasal discharge showed no positive results. To facilitate diagnosis and to reduce the inflammation, we performed an exploratory tympanotomy and biopsy of the epipharynx under general anesthesia. The pathological findings were consistent with Mycobacterium tuberculosis infection. Anti-tuberculosis chemotherapy was performed for one year and the epipharynx granuloma disappeared and the facial nerve palsy was reduced. The present case suggests that it can be difficult to diagnose tuberculosis and that it is very important to consider tuberculosis in cases of intractable inflammation of the head and neck region.
\end{abstract}

Key words : epipharyngeal tuberculosis, facial palsy, exploratory tympanotomy

\section{はじめに}

耳鼻咽喉科領域に拈ける結核症は最近は少なくなって いるが，常に念頭において診察しなければならない疾患 である、また，塗沫検査にて結核菌の同定がされない場 合診断に苦慮することも少なくない1).今回我々は上咽 頭肉芽, 左耳漏, 左顔面神経麻痺を主訴に来院し, 確定 診断のために全麻下に試験的鼓室開放術および上咽頭生 検を施行し, 左中耳結核を伴う上咽頭結核と診断した症 例を経験したので報告する.

\section{症例}

患者：41歳, 女性.

主訴 : 左耳漏, 左顔面神経麻痺.

既往歴：特記すべきことなし。
家族歴：特記すべきことなし.

現病歴: 平成 8 年 4 月初めより左渗出性中耳炎を認め, 鼓膜チューブ留置術を施行された，耳漏が軽減しないた め同年 6 月 6 日某病院受診し, 上咽頭耳管開口部に隆起 性病変を指摘された。上咽頭癌が疑われ生検を施行され たが，非特異的炎症所見のみであった。 7 月 7 日より左 顔面神経麻痺が出現したため, 7 月 8 日当科紹介受診と なった。

初診時所見：左鼓膜チューブより乳白色の耳漏が認め られた。また，左上咽頭耳管開口部から上咽頭後壁にか けて肉芽槉病変を認め, 口ーゼンミューラー窩は消失し ていた（図 1 )。粘膜には軽度の発赤を認め, 潰瘍形成や 白苔の付着はなかった。左顔面神経麻痺は末梢性で麻痺 スコアは $2 / 40$ 点. 部位診断では, シルマーテストにお 

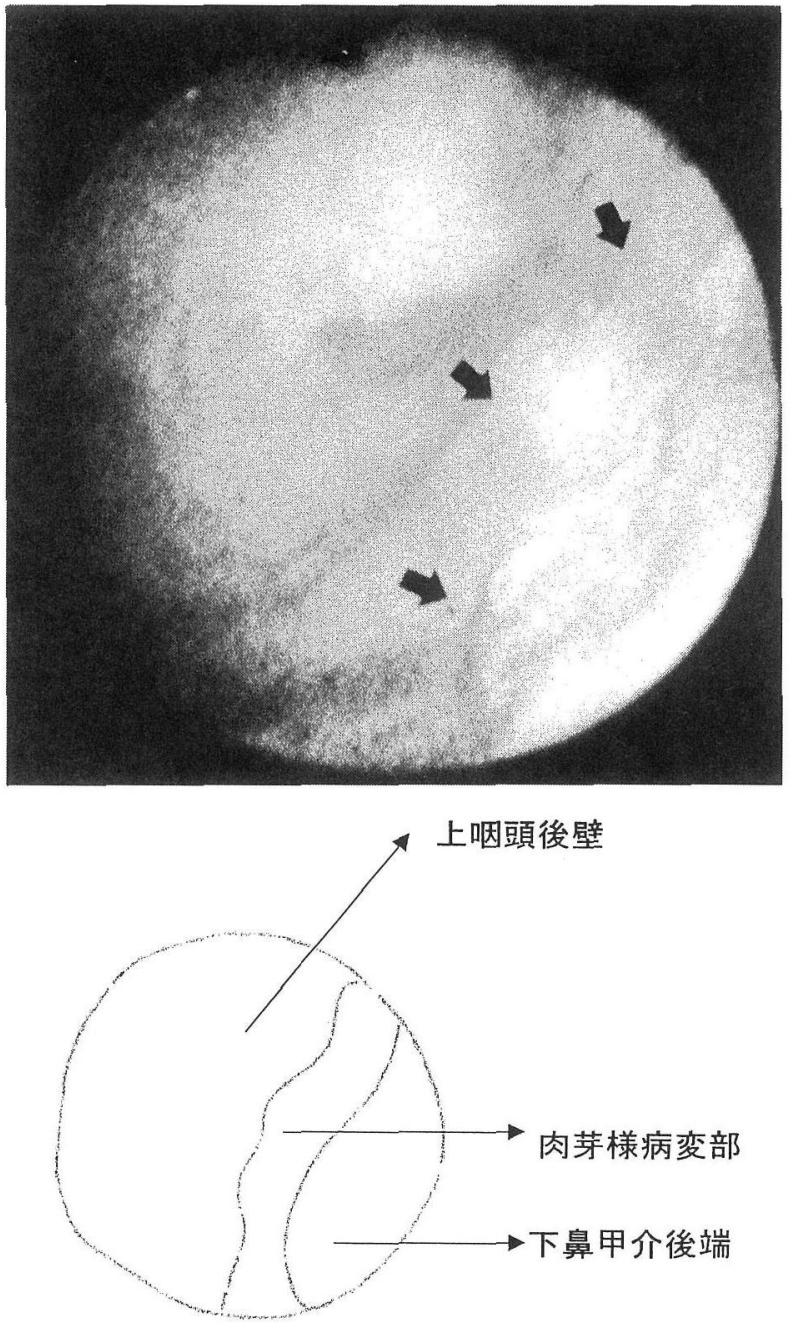

図1上咽頭耳管開口部を示す。 矢印は肉芽様病変部.

いて左右差なく, 電気味覚検查に扔いて右 $: 4 \mathrm{~dB}$, 左 : スケールアウトであり，鼓室部に抢ける麻痺が疑われた。 検査所見：聴力検査にて左混合性難㯖を示した(図 2 ). 血液検查では白血球7, 900, CRP 0.5 の他は著変が なかった。上咽頭の肉芽を生検した病理組織では上皮下 に著明なリンパ球浸潤と壞死を伴ら類上皮性肉芽腫が認 められた。チールニールセン染色は陰性であった．結核 やサルコイドーシスなどが疑われたが, ッベルクリン反 応は $0 / 30 \times 22 \mathrm{~mm}$, 胸部 $X$ 線は正常で, 数回の喀痰, 耳 漏の塗洙検査で結核菌陰性であった。

$\mathrm{CT}$ 所見：上咽頭左側壁は中耳に向かって造影され， ローゼンミューラー窩は消失していた。鼓室, 乳突洞に

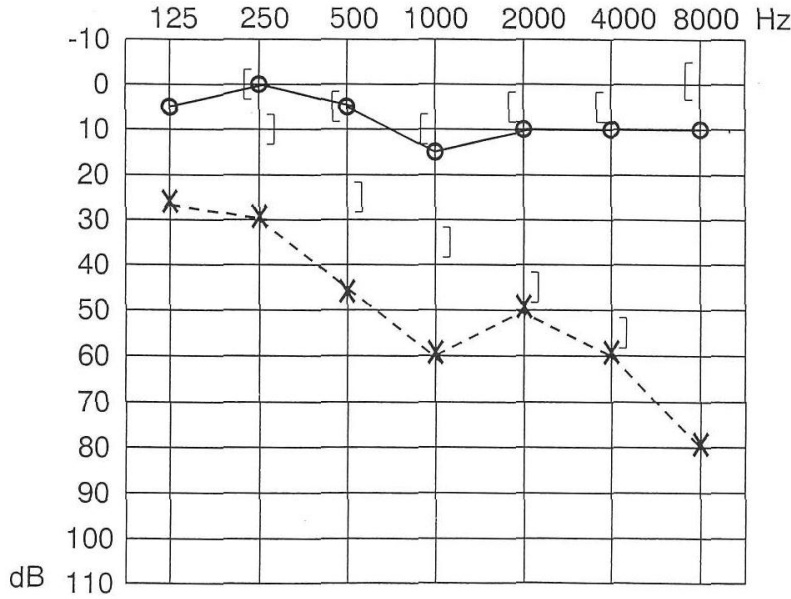

図 2 初診時聴力所見

はびまん性に軟部陰影が認められた（図３）。

MRI 所見 : T2 強調画像で上咽頭左側壁から乳突洞に かけて高信号を示した。

臨床経過：以上の経過より上咽頭結核，中耳結核を疑 らも確定診断には至らず，また高度の顔面神経麻痺を認 めることより培着結果を待てないと考光, 確定診断と中 耳病変部の郭清を目的として 7 月 19 日, 全麻下に試験的 鼓室開放術と上咽頭生検とを施行した。耳管開口部から 鼓室, 乳突洞にかけて白色の肉芽組織で充満していた

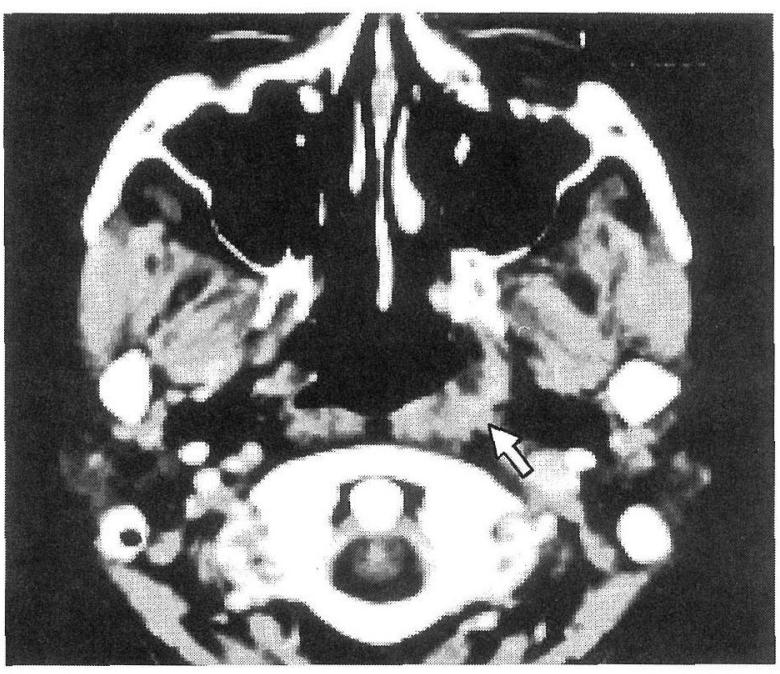

図 3 造影 CT 所見

矢印は造影された上咽頭左側壁をさす。鼓室, 乳突洞に 軟部陰影を認める。 


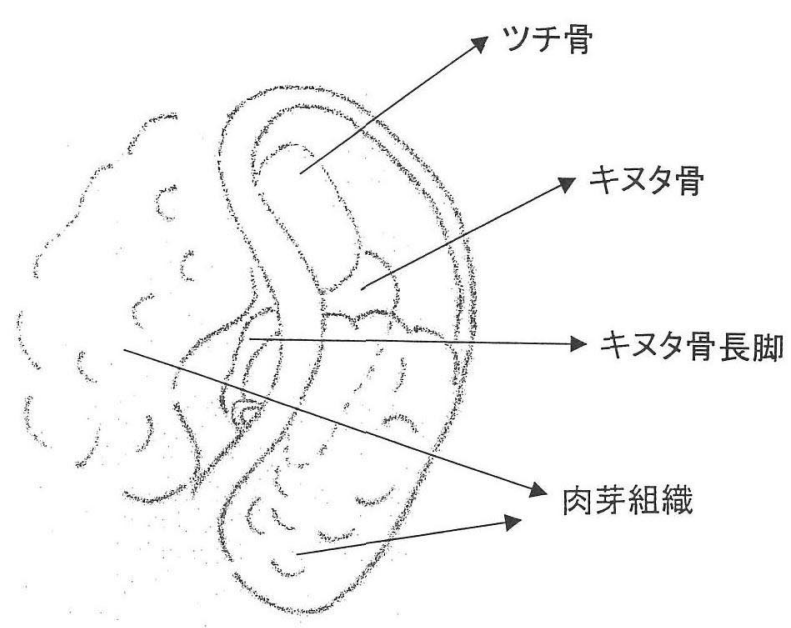

図 4 術中所見

(図 4). ッチ骨, キヌタ骨とともに肉芽組織を除去し, 鼓膜の再建は行わなかった。 また, 水平部の顔面神経管 の破壊は認めなからた。上咽頭生検部の組織は乾酷壞死 巣を取り囲むラングハンス巨細胞を伴った類上皮細胞を 認め, 周囲に多数のリンハ球の浸潤がみられた(図 5 ).

咽頭粘液, 鼓室肉芽の塗沫検査はガフキー6 号であった. この結果, 上咽頭結核㧊よび中耳結核と診断し, 転院後 SM, RFP, INH による抗結核治療を開始した。

その後の経過：9月に初診時の耳漏の培養結果が報告 され，結核菌であることが確認された。治療開始後 3 力 月で耳漏は消失し 6 カ月後には鼓膜穿孔は閉鎖しないま ま乾燥状態となった。耳小骨を再建していないため, 聴 力の改善は認められなかった. 10 力月後には上咽頭肉芽 が消失した. 顔面神経麻痺のスコアも34/40 点と改善し, 約 1 年で投薬終了となった.

\section{考察}

1987年から1996年の10年間に報告された上咽頭結核症 例は検索し之た範囲では18例であり，そのらら中耳結核 を合併した症例は 4 例で，顔面神経麻痺を合併した症例 は1例であった1)。また，胸部X線で異常を認めた症例 は7 例であった22 7)(表 1). 以下に本症例に拈ける感染 経路, 診断方法, 顔面神経麻痺に関する考察を加光る.

\section{1) 感染経路}

上咽頭結核の感染経路についてはその多くが肺からの 管内性感染による二次的なものと考えられているが，近 年原発性上咽頭結核の報告も多(18) 11). 本症例に扣い
ても胸部 X線で異常を認めず，また慢性中耳炎，鼓膜穿 孔などの既往もないことから，原発性に上咽頭に結核病 巣を生じ, 経耳管的に中耳結核を起こしたものと推論し た.上咽頭結核には滲出性中耳炎を合併することが多く, 耳閉感, 難聴, 耳鳴, 耳漏のよらな耳症状が認められる ことがある2(3)9). 今回の症例のように鼓膜切開, チュー ブ留置後も耳漏が続き通常の抗生剤で改善しないよらな 場合, 結核も含めた上咽頭病変を念頭に扣き, ファイ バースコープ検査, CT 検査, 菌検査を考慮しなければ ならないと考光る。

2) 診 断

上咽頭結核の診断に対しては, 胸部X線, ッベルクリ ン反応などの諸検査は有用であるが，確定診断は結核菌 の塗沫検査, 培養検査, 生検による組織診断によりなさ れる4).耳漏や咽頭粘液の塗沫標本に执ける結核菌陽性 率は低く(12)4)8111), 本症例に和いても, 初診時より数度 の塗沫検査はすべて陰性であった。 また，結核菌培養は 結果が出るまでに $4 \sim 8$ 週間かかるため, 顔面神経麻痺 の進行や内耳症状が出現し早期診断が必要な場合は検査 結果の迅速性からも生検が診断の決め手になると考えら れた。しかし本症例では, 外来での生検の組織診断では 結核やサルコイドーシスが疑われるものの, 確定診断に は至らなかった。これは患者の苦痛を考慮し，少量の組 織しか採取できなかったためと考えられる。このよらに 上咽頭結核, 中耳結核を疑っているが確定診断が得られ ず，顔面神経麻痺のような合併症を認め早期の診断，治 療が必要な場合には, 全麻下での上咽頭生検を行らのも

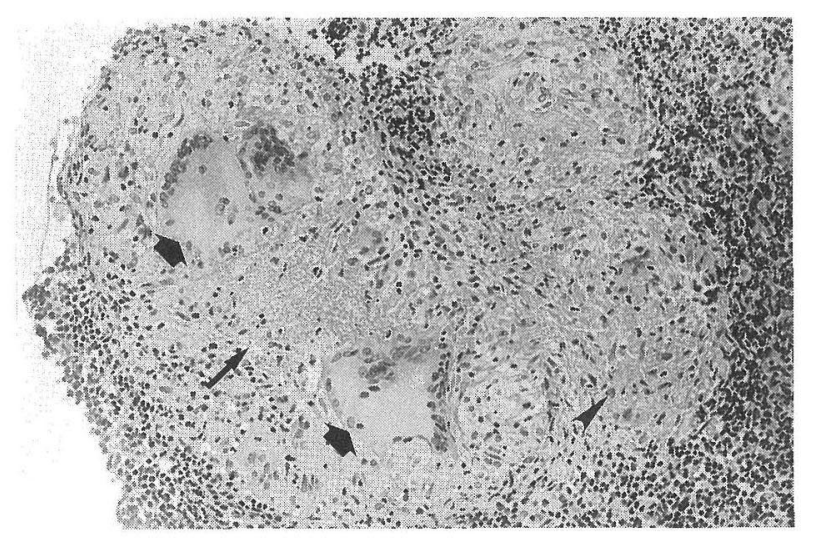

図 5 上咽頭組織所見 $(\mathrm{HE}$ 染色 $\times 200)$

太い矢印はラングハンス巨細胞, 細い矢印は乾酪壊死巣 を示す. 矢頭は類上皮細胞をさす. 
表 1 本邦報告例 (1987年～1996年)

\begin{tabular}{|c|c|c|c|c|}
\hline 報告者 & 主 & 胸部X線所見 & 結核性中耳炎 & 顔面神経麻痺 \\
\hline 新井ら1) & 右難聴, 右耳痛 & - & + & + \\
\hline 菅田ら 2) & 左耳閉感 & + & + & - \\
\hline 菅田ら²) & 鼻閉 & + & - & - \\
\hline 西村 $5^{3)}$ & 左耳閉感, 左耳鳴 & + & - & - \\
\hline 榎本ら ${ }^{4)}$ & 頸部腫瘤 & + & - & - \\
\hline 江崎ら5) & 右耳閉感 & + & - & - \\
\hline 西崎ら6) & 右耳閉感, 右難聴 & + & - & - \\
\hline 山本 $5^{7)}$ & 左耳閉感 & + & - & - \\
\hline 宮野 ${ }^{8)}$ & 右難聴，右耳閉感 & - & - & - \\
\hline 石塚 $5^{9)}$ & 右頸部リンパ節腫脹 & - & - & - \\
\hline 石塚 $5^{9)}$ & 左耳閉感 & - & - & - \\
\hline 石塚 $5^{9)}$ & 咽頭痛 & - & - & - \\
\hline 川原 $5^{10)}$ & 右耳漏 & - & + & - \\
\hline 中山5 & 左耳閉感 & - & - & - \\
\hline 弓立5 18) & 咽頭痛 & - & - & - \\
\hline 大橋ら ${ }^{19)}$ & 頸部リンパ節腫脹 & - & - & - \\
\hline 坂本 ${ }^{20)}$ & 左耳鳴 & - & + & - \\
\hline 依岡ら 21$)$ & 咽頭痛 & - & - & - \\
\hline 自験例 & 左耳漏, 左顔面神経麻痺 & - & + & + \\
\hline
\end{tabular}

一つの方法であると考学る12) 14). また近年組織を検体 として直接結核菌を検出する遺伝子診断法である PCR 法が用いられ始めて捈り115), 診断の一助として施行す るべきであったと考えている.

3 ) 顔面神経麻痺

中耳結核に括ける顔面神経麻痺の合併率は非結核性中 耳炎より高いといわれている。一般に中耳炎による顔面 神経麻痺の成立機序に関しては多くの説があり，急性で は toxic neuritis, vasomotor paresis, 分泌物の神経管圧 迫执よび炎症の神経自身への波及が考光られている16). 中耳結核が上記のどの機序により顔面神経麻痺を起こす ことが多いかは検索し得なかったが，今回の症例では鼓 室部に扣ける麻痺が考えられたことと, 顔面神経管の裂 隙が鼓室部に多いことより ${ }^{17)}$, 顔面神経管の破壊は認め なかったものの, この裂隙を通して直接炎症が神経に波 及したものと推論した。

\section{まとめ}

1) 中耳結核を伴う上咽頭結核を報告した.

2 ）局麻下での上咽頭生検や塗沫検査, ツベルクリン 反応によっても確定診断が得られず, 顔面神経麻痺の進 行が認められたため, 全麻下にて上咽頭生検と試験的鼓 室開放を施行し, 中耳結核を伴ら上咽頭結核の診断を得 た。

3）上咽頭の肉芽病変や難治性中耳炎の際, 胸部 X線 で異常がなくとも結核感染を常に念頭にいれるべきと思 われた。

本論文の要旨は第59回耳鼻咽喉科臨床学会 (京都)にて口演し た.

\section{参考文献}

1 ) 新井雅之, 伊藤博之, 平出文久: 診断的治療を試みた結核 性中耳炎症例. JOHNS $12: 274 \sim 281,1996$. 
2 ) 菅田吉範, 平川勝洋, 渡部雄二, 他 : 最近の上咽頭結核の 2 症例. 耳鼻 $33: 797 \sim 801,1987$.

3 ）西村啓三，久保正治，三木祐一郎，他：最近経験した上咽 頭結核と口蓋扁桃結核の 2 症例について.南大阪医学 41 : $171 \sim 175,1993$.

4 ) 榎本冬樹, 斎藤秀樹, 安藤一郎 : 上咽頭結核例. 耳鼻臨床 $89: 321 \sim 325,1996$.

5 ）江崎祐介, 中井義明, 大橋淑宏, 他 : 陳旧性上咽頭結核例. 耳鼻臨床 $85: 227 \sim 231,1992$.

6 ）西崎和則, 斎藤龍介, 金谷 真, 他 : 上咽頭結核の 1 症例. 耳喉頭頸 $63: 35 \sim 38,1991$.

7 ) 山本史郎, 和久田幸之助：上咽頭結核の 1 症例. 日耳鼻 $92: 1313,1989$.

8 ）宮野竜太, 中島庸也, 森山 寛: 癒着性中耳炎を伴った上 咽頭結核の 1 症例. 耳展 $38: 58 \sim 63,1995$.

9 ) 石塚洋一, 高山孝治, 前田秀彦: 原発性上咽頭結核の 3 症 例. 耳鼻臨床 $89: 25 \sim 30,1996$.

10）川原孝文, 宮口 衛, 石田京子 : 結核性中耳炎を併発した 上咽頭結核の 1 例と文献的考察. 日耳鼻 $93: 1222 \sim 1226$, 1990.

11）中山杜人, 名取雄司, 吉沢正文, 他 : 胸部に異常を認めな かった上咽頭結核の 1 例. 結核 $63: 185 \sim 189,1988$.

12）武林 悟, 児玉 章, 野末道彦, 他 : 頭頸部領域の結核症.
耳鼻臨床 $86: 1457 \sim 1466,1993$.

13）内田真哉, 小野寿之, 村上 泰, 他 : 原発性結核性中耳炎 の 1 例. 耳喉頭頸 $68: 255 \sim 258,1996$.

14）宮下 弘，石田直人，松浦由美子, 他 : 結核性中耳炎の 8 例について. 耳鼻臨床 $85: 365 \sim 372,1992$.

15）宮下 弘：結核性中耳炎. JOHNS 9 : 939 945, 1993.

16）瀧本 勲, 山田一美: 炎症性顔面神経麻痺. JOHNS 3: 427 430, 1987.

17）小川 明 : 顔面神経の解剖. JOHNS 3 : 359 363, 1987.

18）弓立史善, 石丸咲恵, 義沢雄介, 他 : 上咽頭結核に伴った バザン硬結性紅班様結核疹の 1 例. 皮膚臨床 $49: 321 \sim 323$, 1995.

19）大橋一正, 䆶田哲昭, 海野博之, 他: 菌を検出し得た上咽 頭結核の 1 症例. 神奈川医学会雑誌 $18: 318,1992$.

20）坂本邦彦, 松山博文, 内㝨明裕, 他: 上咽頭結核の 1 症例. 耳展 $31: 851 \sim 856,1988$.

21）依岡典子, 天野一, 岸本誠司 : 上咽頭結核の 1 症例. 日 耳鼻 $90: 283,1987$.

$$
\left.\begin{array}{l}
\text { 原稿受付 : 平成 } 10 \text { 年 } 5 \text { 月 } 8 \text { 日 } \\
\text { 原稿採択 : 平成 } 10 \text { 年 } 7 \text { 月 } 29 \text { 日 } \\
\text { 別刷請求先 : 牧石千晶 } \\
\text { T663-8131 兵庫県西宮市武庫川1-1 } \\
\text { 兵庫医科大学耳鼻咽喉科学教室 }
\end{array}\right)
$$

